Chapter 12

\title{
Role of the Genetic Factors in the Development of Myopia
}

\author{
Malgorzata Mrugacz \\ Additional information is available at the end of the chapter \\ http://dx.doi.org/10.5772/52543
}

\section{Introduction}

Myopia, also known as nearsightedness, is the most common eye disorder worldwide. In myopic peoples, the image of distant objects falls in front of the retina, either as the eye is too long (axial myopia), the cornea is too convex or the index of refraction of the lens is too high (refractive myopia). The light enteringthe eye is not focused correctly and distant objects look blurred [1]. The myopic eye is generally vulnerable and persons with $\leq-6.0$ diopters (D) are more liable to a wide range of ocular pathologies. The development of highgrade myopia involves anterior-posterior enlargement of the eye, scleral thinning, changes in the diameter of scleral collagen fibrils, and frequent detachment of the retina resulting from stress related with axial elongation [2].

\section{Epidemiology}

The prevalence of myopia often varies with age, country, sex, race, ethnicity, occupation and environment [3]. In general, myopia firstly occurs in school-age children, and typically progresses until about the age of 21 , because the eye continues to grow during childhood. However, myopia may also develop in adults due to visual stress or health conditions such as diabetes [4].

Myopia affects $25 \%$ people over age 40 in the Western Europe and the United States, making this condition the most common eye disorder in the West and constituting a significant public health and economic problem $[5,6]$. The cost of optical correction to provide clear distinct vision is considerable. Moreover, the development of high-grade myopia ( $\leq-6.0$ diopters [D]) [7] is a significant risk factor for other ocular diseases, includingperipheral retinal and cho- 
roidal degenerations, glaucoma, retinal detachment, premature cataracts, and finally blindness [8-10]. Consequently, great efforts have been undertaken to identify and understand the mechanisms underlying the development and progression of myopia. The estimated prevalence of high grade myopia is $\sim 2.5$ to $9.6 \%$ in the elderly world population $[7,8]$. However, its highest prevalence rates are in Asians, in whom almost 50 to $80 \%$ of the adult populations are myopic [10-12]. Recent population-based studies suggest that the prevalence is increasing, specifically in Asian populations. In some areas, such as China, India and Malaysia, up to $41 \%$ of the adult population is myopic to -1 diopters, up to $80 \%$ to -0.5 diopters. In some urban areas in East Asia, the prevalence of myopia amnong teenagers and young adults exceeds $70 \%$ [13]. A recent review observed that $26.6 \%$ of Western Europeans aged 40 or over have at least -1.0 diopters of myopia, and $4.5 \%$ have at least -5.0 diopters [7]. In China, myopia rate was the highest in the world: 400 milion people are myopic out of its 1.3 bilion people. The prevalence of mtopia is $77.3 \%$ in high school students in China, and is more than $80 \%$ in college students. The prevalence of myopia has been reported as high as $70 \%-90 \%$ in some Asian countries, 30\%-40\% in Europe and the Unites States, and 10\%-20\% in Africa. By the year 2020, it is estimated that 2.5 bilion people- $30 \%$ of the world's population- will be affected by myopia alone. Myopia is less common in the african population and associated diaspora. In American people between the age of 12 and 54, myopia has been observed to affect African Americans less than Caucasians. Asians had the highest prevalence followed by Hispanics. Caucasians had the lowest prevalence of myopia [7].

In addition, a number of studies have found that the incidence of myopia increases with level of education and many studies have shown a correlation between myopia and higher intelligence quotient (IQ), possibly due to the confunding factor of formal education [4].

\section{Environmental and genetic factors in myopia}

Myopia has a diverse etiology, with both environmental and genetic factors believed to be involved in the condition's development and progression. Whether myopia is due to interethnic differences in the genetic predisposition to myopia or to culture-specific environmental influences remains uncertain.

The environmental factors implicated in myopia include near work, light exposure, lack of physical activity, diet, a higher level of education, and urbanization [14-17]. For instance, population-based studies have ahown associations between myopia and higher socioeconomic status and greater levels of educational attainment [18]. High prevalences and progression rates of myopia have been reported in individuals in visually intensive occupations such as clinical microscopists, carpet weavers and visual display workers [19]. Within the context of the myopization proces, education, socioeconomic status, and occupation are generally considered to be indirect surrogates for more proximal risk factors such as near-work visual demand. Studies of the effect of reading have attempted to show a more direct relationship between myopia and near work activity. Children with myopia spent more time studying, reading, and less time playing sports than children without myopia. Studies on 
the effect of reading on the rate of progression of myopia have provided conflicting results. In the study of Singaporean school children, near work was not associated with worsening myopia [20]. On the other hand, myopis children in Finland who spent more time reading had faster rates of myopia progression [21]. The relationship between reading, near work activity and myopia is complex and still poorly understood. Assesment of exposure to near worki s subject to considerable measurement error and is prone to bias in retrospective studies. Effect estimates may vary depending on the unit of measurement chosen (i.e. intensity, duration, reading distance or cumulative dose), outcome definitions (myopia, refractive error, rates of progression), or the ages, ethnicities and social circumstances. The current ubiquity of technologies such as computers, cellular and smart phones, and gaming devices has added a layer of complexity to the near work question. Indeed, it could be argued that the recent increase in myopia prevalence in East Asia reported in some studies may be the result of a steady rise in the use of modern electronic devices over the past three decades. Nevertheless, a direct link between the utilization of electronic devices and myopia development has yet to be convincingly established and future studies should attempt to validate and quantify this relationship [22].

While excessive reading or near work activity increase the risk of myopia, other environmental factors (such as playing sports and time spent outdoors) have shown protective relationships. Recent studies have shown that time spent outdoors and participation in outdoor sports during childhood is associated with a decreased risk of myopia [15]. Moreover, the beneficial effect of outdoor activity appears not to be the result of a concomitant reduction in near work. There is also evidence that genetic factors may interact with outdoor activity on the risk of myopia. The inverse relationship between outdoor activity and myopia development may be limited to children with a strong familial predisposition to myopia such as children with two myopic parents compared to children with either no, or one myopic parent.

While behawior and environment play important roles in refractive development, it has been convincingly established that heritable (presumbly genetic) factors, are also important in ocular refraction. Familial aggregation studies have estimated sibling recurrence risks of common forms of refractive errors to range from 2 to 5.61 for myopia [23,24]. Moreover, children of myopic parents tend to have longer eyes and are more likely to develop myopia during childhood or adolescence. The strong familial effects for refraction phenotypes are present across populations with varying underlying distributions of refractive error. This observation is consistent with the hypothesis that environmental influences may drive regional and ethnic differences in refractive distribution, but that within-population variation is largely due to genetic factors.

However, HM is highly heritable and often appears as familial ocular disorder, where genetic predisposition seems to be a dominant factor of its development and progression [25-27]. Each type of Mendelian inheritance for familial HM has been described [28,29]. Myopia related genes include about 70 genetic loci to which primary myopias have been mapped, although the numer is constantly increasing and depends to some extent on definition. Of these, several are associated with additional abnormalities, mostly as part of developmental 
syndromes. These tend to result from mutations in genes encoding transcriptional activators, and most of these have been identified by sequencing candidate genes in patients with developmental syndromes [3].

To date, several genetic loci for nonsyndromic myopia $(M Y P)$ have been mapped, including 12 loci linked to HM: MYP1, chromosome Xq28, MYP2 18p11.31, MYP3 12q21-q23, MYP4 7q36, MYP5 17q21-q22, MYP11 4q22-q27, MYP12 2q37.1, MYP13 Xq23-q25, MYP15 10q21.1, MYP16 5p15.33-p15.2 ; MYP18 14q22.1-q24.2, and MYP19 5p15.1-p13.3 [30-45]. Moreover, two recent independent genome-wide association studies involving large cohorts of refractive error patients identified loci at chromosome 15q14 and 15q25 [46,47].

Candidate gene association studies have revealed several HM susceptibility genes, including: collagen, type I, alpha 1 (COL1A1), transforming growth factor, beta 1 (TGFB1), transforming growth beta-induced factor (TGIF), lumican (LUM), hepatocyte growth factor (HGF), myocilin (MYOC), paired box 6 (PAX6), and uromodulin-like 1 (UMODL1) [48-62]. However, positive results have not been replicated, and inconsistent data have been published. Thus, the causative mutation(s) has not yet been found, suggesting genetic heterogeneity among studied populations.

A genetic association between the three single nucleotide polymorphism (SNP)s rs6214, rs10860860, and rs2946834 and familial myopia in a large, international cohort of myopia pedigrees of Caucasian origin, suggests that insulin-like growth factor 1 (IGF-1) may be a candidate gene for HM [63]. These three SNPs are located within the MYP3 locus mapped to chromosomal region 12q21-q23. This locus was previously reported to be associated with autosomal dominant HM. The SNP rs6214 (reference allele G) lies in the 3'-untranslated region (UTR) of IGF-1, whereas the SNPs rs10860860 (reference allele A) and rs2946834 (reference allele $\mathrm{C}$ ) are located in the noncoding sequence in close proximity to IGF-1 [34,35].

The IGF-1 gene encodes insulin-like growth factor (pIGF-1), which is a member of the signaling system involved in development, cellular growth, differentiation, protein translation, metabolism, apoptosis, and aging [64,65]. The association of IGF-1 with numerous human diseases, such as diabetes, cancer, and growth failure has been reported. IGF-1 has been also implicated in ocular diseases, including retinopathy of prematurity, age-related macular degeneration, and diabetic retinopathy [66-73]. The IGF-1 gene polymorphisms investigations in Polish families do not suport the studies reporting association of the SNPs rs 6214, rs10860860, and rs2946834 in the IGF-1 gene with HM and any myopia phenotypes [74]. Haplotype analysis with informative crossovers in affected individuals defined a 12.2; 10.9; and $9.5 \mathrm{Mb}$ genomic regions for high-grade myopia spanned between SNP markers rs11977885/rs10950639, rs11770622/rs9719399, and rs4763417/rs10842388 on chromosomes 7p22.1-7p21.1, 7p12.3-7p11.2, and 12p12.3-12p12.1 [75]. However, the polymorphism of rs12423791in the Chinese population showed positive association with extreme myopia $[76,77]$. Further replication studies involving other populations are needed to investigate the possible role of IGF-1 as a potential myopia candidate gene.

Quantitative analyses of 225 Caucasian families identified two additional potential loci at chromosome 6q13-16.1 and chromosome 5q35.1-35.2 for myopia [78]. 


\section{Preventive measures and treatment}

Treatments that are currently available for slowing the progression of myopia include spectacle lenses, contact lenses, and pharmaceutical agents such as a non-selective muscarinic antagonist (Atropine). Several large studies conducted indifferent parts of world have shown that the prevalence of myopia in children with more outdoor activity hours is lower than in children with fewer hours.

\section{Conclusion}

Uncorrected refractive errors such as myopia and hyperopia aren the most common causes of visual impairment worldwide. It is estimated that 2.5 bilion people will be affected by myopia within the next decade. Epidemiologica, experimental and clinical research has shown that refractive development is influenced environmental and genetic factors for myopia. Genetic linkage studies have mapped the dozen loci, while association studies have found more than 70 different genes. Many of these genes are involved in common biological pathways to known to mediate extracellular matrix composition and regulate connective tissue remodelling. Other associated genomic regions suggest novel mechanisms in the etiology of high myopia, such as mitochondrial-mediated cell death and photoreceptor-mediated visual signal transmission. The interactions between genes and environmental factors may be significant in determing individual risks of high myopia, and may help explain the pathogenetic mechanisms of myopia in human population.

\section{Author details}

Malgorzata Mrugacz*

Address all correspondence to: malgorzata.mrugacz@umb.edu.pl

Medical University of Bialystok, Poland

\section{References}

[1] Llorente L, Barbero S, Cano D, Dorronsoro C, Marcos S. Myopic versus hyperopic eyes: axial length, corneal shape and optical aberrations. J Vis. 2004;4:288-98.

[2] Burton TC. The influence of refractive error and lattice degeneration on the incidence of retinal detachment. Trans Am Ophthalmol Soc. 1989;87:143-55.

[3] Yu L, Li ZK, Gao JR, Liu JR Xu CT. Epidemiology, genetics and treatments for myopia. Int J Ophthalmol. 2011;4(6):658-669. 
[4] Siegwart JT Jr, Norton TT. Perspective: how might emmetropization and genetic factors produce myopia in normal eyes? Optom Vis Sci. 2011;88(3):365-372.

[5] Pararajasegaram R. VISION 2020-the right to sight: from strategies to action. Am J Ophthalmol. 1999;128:359-60.

[6] Vitale S, Cotch MF, Sperduto R, Ellwein L. Costs of refractive correction of distance vision impairment in the United States, 1999-2002. Ophthalmology 2006;113:2163-70.

[7] Kempen JH, Mitchell P, Lee KE, Tielsch JM, Broman AT, Taylor HR, Ikram MK, Congdon NG, O'Colmain BJ. The prevalence of refractive errors among adults in the United States, Western Europe, and Australia. Arch Ophthalmo.1 2004;122:495-505.

[8] Wong TY, Foster PJ, Hee J, Ng TP, Tielsch JM, Chew SJ, Johnson GJ, Seah SK. Prevalence and risk factors for refractive errors in adult Chinese in Singapore. Invest Ophthalmol Vis Sci. 2000;41:2486-94.

[9] Hosaka A. Population studies-myopia experience in Japan. Acta Ophthalmol Suppl. 1988; 185:37-40.

[10] Chandran S. Comparative study of refractive errors in West Malaysia. Br J Ophthalmol. 1972;56:492-5.

[11] Wu HM, Seet B, Yap EP, Saw SM, Lim TH, Chia KS. Does education explain ethnic differences in myopia prevalence? A population-based study of young adult males in Singapore. Optom Vis Sc.i 2001;78:234-9.

[12] Kleinstein RN, Jones LA, Hullett S, Kwon S, Lee RJ, Friedman NE, Manny RE, Mutti DO, Yu JA, Zadnik K. Refractive error and ethnicity in children. Arch Ophthalmol. 2003; 121:1141-7.

[13] Lin LL, Shih YF, Tsai CB, Chen CJ, Lee LA, Hung PT, Hou PK. Epidemiologic study of ocular refraction among schoolchildren in Taiwan in 1995. Optom Vis Sci. 1999;76:275-81.

[14] Mutti DO, Mitchell GL, Moeschberger ML, Jones LA, Zadnik K. Parental myopia, near work, school achievement, and children's refractive error. Invest Ophthalmol Vis Sci. 2002; 43:3633-40.

[15] Jones LA, Sinnott LT, Mutti DO, Mitchell GL, Moeschberger ML, Zadnik K. Parental history of myopia, sports and outdoor activities, and future myopia. Invest Ophthalmol Vis Sci. 2007; 48:3524-32.

[16] Cordain L, Eaton SB, Brand MJ, Lindeberg S, Jensen C. An evolutionary analysis of the aetiology and pathogenesis of juvenile-onset myopia. Acta Ophthalmol Scand. $2002 ; 80: 125-35$.

[17] Czepita D, Goslawski W, Mojsa A, Muszyñska-Lachota I. Role of light emitted by incandescent or fluorescent lamps in the development of myopia and astigmatism. Med Sci Monit. 2004;10:168-71. 
[18] Wong TY, Foster PJ, Johnson GJ. Education, socioeconomic status and ocular dimenssions in Chinese adults. The Tanjong Pagar Survey. Br J Ophthalmol. 2001;86:963-968.

[19] Siemensen B, Thorud LO. Adult-onset myopia and occupation. Acta ophthalmologica. 1994;2:469-471.

[20] Saw SM, Nieto FJ, Katz J. Factors related to the progression of myopia in Singaporean children. Optom Vis Sci. 2000;77:549-554.

[21] Parssinen O, Hemminki E, Klemetti A. Effect of spectacle use and accomodation on myopic progression: final results of a three-years randomised clinical trials among schoolchildren. Br J Ophthalmol. 1989;73:547-551.

[22] Wojciechowski R. Nature and nurture: the complex genetics of myopia and refractive errors. Clin Genet. 2011;79(4):301-320.

[23] Wojciechowski R, Congdon N, Bowie H. Heritability of refractive errors and familial aggregation of myopia in an elderly American population. Ivest Ophthalmol Vis Sci. 2005;46:1588-1592.

[24] Guggenheim JA, Pong-Wong R, Haley CS. Correlations in refractive errors between siblings in the Singapore Cohort Study of risk factors for myopia. Br J Ophthalmol. 2007;91:781-784.

[25] Hammond CJ, Snieder H, Gilbert CE, Spector TD. Genes and environment in refractive error: the twin eye study. Invest Ophthalmol Vis Sci. 2001; 42:1232-6.

[26] Dirani M, Chamberlain M, Shekar SN, Islam AF, Garoufalis P, Chen CY, Guymer RH, Baird PN. Heritability of refractive error and ocular biometrics: the Genes in Myopia (GEM) twin study. Invest Ophthalmol Vis Sci. 2006; 47:4756-61.

[27] Liang CL, Yen E, Su JY, Liu C, Chang TY, Park N, Wu MJ, Lee S, Flynn JT, Juo SH. Impact of family history of high myopia on level and onset of myopia. Invest Ophthalmol Vis Sci. 2004; 45:3446-52.

[28] Sorsby A, Benjamin B. Modes of inheritance of errors of refraction. J Med Genet. 1973; 10:161-4.

[29] Young TL, Metlapally R, Shay AE. Complex trait genetics of refractive error. Arch Ophthalmol. 2007;125:38-48.

[30] Schwartz M, Haim M, Skarsholm D. X-linked myopia: Bornholm eye disease-linkage to DNA markers on the distal part of Xq. Clin Genet. 1990;38:281-6.

[31] Young TL, Deeb SS, Ronan SM, Dewan AT, Alvear AB, Scavello GS, Paluru PC, Brott MS, Hayashi T, Holleschau AM, Benegas N, Schwartz M, Atwood LD, Oetting WS, Rosenberg T, Motulsky AG, King RA. X-linked high myopia associated with cone dysfunction. Arch Ophthalmol. 2004;122:897-908. 
[32] Young TL, Ronan SM, Drahozal LA, Wildenberg SC, Alvear AB, Oetting WS, Atwood LD, Wilkin DJ, King RA. Evidence that a locus for familial high myopia maps to chromosome 18p. Am J Hum Genet. 1998; 63:109-19.

[33] Lam DS, Tam PO, Fan DS, Baum L, Leung YF, Pang CP. Familial high myopia linkage to chromosome 18p. Ophthalmologica 2003;217:115-8.

[34] Young TL, Ronan SM, Alvear AB, Wildenberg SC, Oetting WS, Atwood LD, Wilkin DJ, King RA. A second locus for familial high myopia maps to chromosome 12q. Am J Hum Genet. 1998; 63:1419-24.

[35] Nürnberg G, Jacobi FK, Broghammer M, Becker C, Blin N, Nürnberg P, Stephani U, Pusch CM. Refinement of the MYP3 locus on human chromosome 12 in a German family with Mendelian autosomal dominant high-grade myopia by SNP array mapping. Int J Mol Med. 2008; 21:429-38.

[36] Farbrother JE, Kirov G, Owen MJ, Pong-Wong R, Haley CS, Guggenheim JA. Linkage analysis of the genetic loci for high myopia on 18p, 12q, and 17q in 51 U.K. families. Invest Ophthalmol Vis Sci. 2004;45:2879-85.

[37] Naiglin L, Gazagne C, Dallongeville F, Thalamas C, Idder A, Rascol O, Malecaze F, Calvas P. A genome wide scan for familial high myopia suggests a novel locus on chromosome 7q36. J Med Genet. 2002;39:118-24.

[38] Paluru P, Ronan SM, Heon E, Devoto M, Wildenberg SC, Scavello G, Holleschau A, Mäkitie O, Cole WG, King RA, Young TL. New locus for autosomal dominant high myopia maps to the long arm of chromosome 17. Invest Ophthalmol Vis Sci. 2003; 44:1830-6.

[39] Zhang Q, Guo X, Xiao X, Jia X, Li S, Hejtmancik JF. A new locus for autosomal dominant high myopia maps to 4q22-q27 between D4S1578 and D4S1612. Mol Vis. 2005; 11:554-60.

[40] Paluru PC, Nallasamy S, Devoto M, Rappaport EF, Young TL. Identification of a novel locus on $2 \mathrm{q}$ for autosomal dominant high-grade myopia. Invest Ophthalmol Vis Sci. 2005; 46:2300-7.

[41] Zhang Q, Guo X, Xiao X, Jia X, Li S, Hejtmancik JF. Novel locus for X linked recessive high myopia maps to Xq23-q25 but outside MYP1. J Med Genet. 2006; 43:e20

[42] Nallasamy S, Paluru PC, Devoto M, Wasserman NF, Zhou J, Young TL. Genetic linkage study of high-grade myopia in a Hutterite population from South Dakota. Mol Vis. 2007; 13:229-36.

[43] Lam CY, Tam PO, Fan DS, Fan BJ, Wang DY, Lee CW, Pang CP, Lam DS. A genomewide scan maps a novel high myopia locus to 5p15. Invest Ophthalmol Vis Sci. 2008; 49:3768-78.

[44] Yang Z, Xiao X, Li S, Zhan Q. Clinical and linkage study on a consanguineous Chinese family with autosomal recessive high myopia. Mol Vis. 2009;15:312-8. 
[45] Ma JH, Shen SH, Zhang GW, Zhao DS, Xu C, Pan CM, Jiang H, Wang ZQ, Song HD. Identification of a locus for autosomal dominant high myopia on chromosome 5p13.3-p15.1 in a Chinese family. Mol Vis. 2010;16:2043-54.

[46] Solouki AM, Verhoeven VJ, van Duijn CM, Verkerk AJ, Ikram MK, Hysi PG, Despriet DD, van Koolwijk LM, Ho L, Ramdas WD, Czudowska M, Kuijpers RW, Amin N, Struchalin M, Aulchenko YS, van Rij G, Riemslag FC, Young TL, Mackey DA, Spector TD, Gorgels TG, Willemse-Assink JJ, Isaacs A, Kramer R, Swagemakers SM, Bergen AA, van Oosterhout AA, Oostra BA, Rivadeneira F, Uitterlinden AG, Hofman A, de Jong PT, Hammond CJ, Vingerling JR, Klaver CC. A genome-wide association study identifies a susceptibility locus for refractive errors and myopia at 15q14. Nat Genet. 2010;42:897-901.

[47] Hysi PG, Young TL, Mackey DA, Andrew T, Fernández-Medarde A, Solouki AM, Hewitt AW, Macgregor S, Vingerling JR, Li YJ, Ikram MK, Fai LY, Sham PC, Manyes L, Porteros A, Lopes MC, Carbonaro F, Fahy SJ, Martin NG, van Duijn CM, Spector TD, Rahi JS, Santos E, Klaver CC, Hammond CJ. A genome-wide association study for myopia and refractive error identifies a susceptibility locus at 15q25. Nat Genet. 2010;42:902-5.

[48] Inamori $\mathrm{Y}$, Ota M, Inoko H, Okada E, Nishizaki R, Shiota T, Mok J, Oka A, Ohno S, Mizuki N. The COL1A1 gene and high myopia susceptibility in Japanese. Hum Genet. $2007 ; 122: 151-7$.

[49] Metlapally R, Li YJ, Tran-Viet KN, Abbott D, Czaja GR, Malecaze F, Calvas P, Mackey D, Rosenberg T, Paget S, Zayats T, Owen MJ, Guggenheim JA, Young TL. COL1A1 and COL2A1 genes and myopia susceptibility: evidence of association and suggestive linkage to the COL2A1 locus. Invest Ophthalmol Vis Sci. 2009;50:4080-6.

[50] Hayashi T, Inoko H, Nishizaki R, Ohno S, Mizuki N. Exclusion of transforming growth factor-beta1 as a candidate gene for myopia in the Japanese. Jpn J Ophthalmol. 2007;51:96-9.

[51] Zha Y, Leung KH, Lo KK, Fung WY, Ng PW, Shi MG, Yap MK, Yip SP. TGFB1 as a susceptibility gene for high myopia: a replication study with new findings. Arch Ophthalmol. 2009;127:541-8.

[52] Scavello GS, Paluru PC, Ganter WR, Young TL. Sequence variants in the transforming growth beta-induced factor (TGIF) gene are not associated with high myopia. Invest Ophthalmol Vis Sci. 2004;45:2091-7.

[53] Pertile KK, Schäche M, Islam FM, Chen CY, Dirani M, Mitchell P, Baird PN. Assessment of TGIF as a candidate gene for myopia. Invest Ophthalmol Vis Sci. 2008; 49:49-54.

[54] Wang P, Li S, Xiao X, Jia X, Jiao X, Guo X, Zhang Q. High myopia is not associated with the SNPs in the TGIF, lumican, TGFB1, and HGF genes. Invest Ophthalmol Vis Sci. 2009;50:1546-51. 
[55] Lin HJ, Wan L, Tsai Y, Chen WC, Tsai SW, Tsai FJ. The association between lumican gene polymorphisms and high myopia. Eye (Lond). 2010;24:1093-101.

[56] Han W, Yap MK, Wang J, Yip SP. Family-based association analysis of hepatocyte growth factor (HGF) gene polymorphisms in high myopia. Invest Ophthalmol Vis Sci. 2006; 47:2291-9.

[57] Yanovitch T, Li YJ, Metlapally R, Abbott D, Viet KN, Young TL. Hepatocyte growth factor and myopia: genetic association analyses in a Caucasian population. Mol Vis. 2009; 15:1028-35.

[58] Tang WC, Yip SP, Lo KK, Ng PW, Choi PS, Lee SY, Yap MK. Linkage and association of myocilin (MYOC) polymorphisms with high myopia in a Chinese population. Mol Vis. 2007;13:534-44.

[59] Zayats T, Yanovitch T, Creer RC, McMahon G, Li YJ, Young TL, Guggenheim JA. Myocilin polymorphisms and high myopia in subjects of European origin. Mol Vis. 2009; 15:213-22.

[60] Hewitt AW, Kearns LS, Jamieson RV, Williamson KA, van Heyningen V, Mackey DA. PAX6 mutations may be associated with high myopia. Ophthalmic Genet. 2007;28:179-82.

[61] Ng TK, Lam CY, Lam DS, Chiang SW, Tam PO, Wang DY, Fan BJ, Yam GH, Fan DS, Pang CP. AC and AG dinucleotide repeats in the PAX6 P1 promoter are associated with high myopia. Mol Vis. 2009;15:2239-48.

[62] Nishizaki R, Ota M, Inoko H, Meguro A, Shiota T, Okada E, Mok J, Oka A, Ohno S, Mizuki N. New susceptibility locus for high myopia is linked to the uromodulin-like 1 (UMODL1) gene region on chromosome 21q22.3. Eye 2009; 23:222-9.

[63] Metlapally R, Ki CS, Li YJ, Tran-Viet KN, Abbott D, Malecaze F, Calvas P, Mackey DA, Rosenberg T, Paget S, Guggenheim JA, Young TL. Genetic association of insulinlike growth factor-1 polymorphisms with high-grade myopia in an international family cohort. Invest Ophthalmol Vis Sci. 2010;51:4476-9.

[64] Werner H, Leroith D. New concepts in regulation and function of the insulin-like growth factors: implications for understanding normal growth and neoplasia. Cell Mol Life Sci. 2000; 57:932-42.

[65] Bartke A. The somatotropic axis and aging: Mechanisms and persistent questions about practical implications. Exp Gerontol. 2009;44:372-4.

[66] Dunger DB, Ong KK, Sandhu MS. Serum insulin-like growth factor-I levels and potential risk of type 2 diabetes. Horm Res. 2003;60:131-5.

[67] Pollak M. Insulin and insulin-like growth factor signalling in neoplasia. Nat Rev Cancer. 2008;8:915-28.

[68] Netchine I, Azzi S, Houang M, Seurin D, Perin L, Ricort JM, Daubas C, Legay C, Mester J, Herich R, Godeau F, Le Bouc Y. Partial primary deficiency of insulin-like 
growth factor (IGF)-I activity associated with IGF1 mutation demonstrates its critical role in growth and brain development. J Clin Endocrinol Metab. 2009;94:3913-21.

[69] Hellström A, Engström E, Hard AL, Albertsson-Wikland K, Carlsson B, Niklasson A, Löfqvist C, Svensson E, Holm S, Ewald U, Holmström G, Smith LE. Postnatal serum insulin-like growth factor I deficiency is associated with retinopathy of prematurity and other complications of premature birth. Pediatrics. 2003; 112:1016-20.

[70] Pérez-Muñuzuri A, Fernández-Lorenzo JR, Couce-Pico ML, Blanco-Teijeiro MJ, Fraga-Bermúdez JM. Serum levels of IGF1 are a useful predictor of retinopathy of prematurity. Acta Paediatr. 2010;99:519-25.

[71] Rosenthal R, Wohlleben H, Malek G, Schlichting L, Thieme H, Bowes Rickman C, Strauss O. Insulin-like growth factor-1 contributes to neovascularization in age-related macular degeneration. Biochem Biophys Res Commun. 2004;323:1203-8.

[72] Bergman PB, Moravski CJ, Edmondson SR, Russo VC, Bach LA, Wilkinson-Berka JL, Werther GA. Expression of the IGF system in normal and diabetic transgenic (mRen-2)27 rat eye. Invest Ophthalmol Vis Sci. 2005;46:2708-15.

[73] Wilkinson-Berka JL, Wraight C, Werther G. The role of growth hormone, insulin-like growth factor and somatostatin in diabetic retinopathy. Curr Med Chem. 2006;13:3307-17.

[74] Rydzanicz M, Nowak DM, Karolak JA, Frajdenberg A, Podfigurna-Musielak M, Mrugacz M, Gajecka M. IGF-1 gene polymorphisms in Polish families with high-grade myopia. Mol Vis. 2011;17:2428-2439.

[75] Rydzanicz M, Nath SK, Sun C, Podfigurna-Musielak M, Frajdenberg A, Mrugacz M, Winters D, Ratnamala U, Radhakrishna U, Bejjani BA, Gajecka M. Identification of novel suggestive loci for high-grade myopia in Polish families. Mol Vis. 2011;17:2028-39.

[76] Zhuang W, Yang P, Li Z, Sheng X, Zhao J, Li S, Yang X, Xiang W, Rong W, Liu Y, Zhang F. Association of insulin-like growth factor-1 polymorphisms with high myopia in the Chinese population. Mol Vis. 2012;18:634-644.

[77] Mak JY, Yap MK, Fung WY, Ng PW, Yip SP. Association of IGF1 gene haplotypes with high myopia in Chinese adults. Arch Ophthalmol. 2012;130(2):209-216.

[78] Abbott D, Li YJ, Guggenheim J, Metlapally R, Malecaze F, Calvas P, Rosenberg T, Paget S, Zayats T, Mackey D, Feng S, Young TL. An international collaborative familybased whole genome quantitative trait linkage scan for myopic refractive error. Mol Vis. 2012;18:720-729. 
